\title{
Antimicrobial Activity and Physicochemical Analysis of Bio-degradable Films from Cucurbita pepo and Musa paradisiaca
}

\author{
J. MORRIS PRINCEY ${ }^{1 *}$, A. NANDHINI ${ }^{2}$, G. POOJADEVI ${ }^{3}$ and S. NOBIL DIVYA ${ }^{4}$ \\ Department of Chemistry, Holy Cross College (Autonomous), Tiruchirapalli-620002, \\ Tamil Nadu, India. \\ *Corresponding author E-mail: princeymorris@gmail.com \\ http://dx.doi.org/10.13005/ojc/370623
}

(Received: July 28, 2021; Accepted: December 01, 2021)

\begin{abstract}
Cucurbita pepo and Musa paradisiaca can be considered as a large source of starch which makes it appropriate to be used for the preparation of Bio-plastic material. In this study, biodegradable films from Cucurbita pepo and Musa paradisiaca were developed and investigated for their properties like $\mathrm{pH}$, ash, moisture content, amylose content, biodegradability, and antimicrobial activity. 1,2,3-Propanetriol, Gingelly oil, and Agarose gel was used to reduce the brittleness of the developed starch-based bioplastic films. The investigation of films was done by Spectroscopic and Surface analysis techniques. The developed Bio-films showed substantial properties like less engorgement and insolubility in water which makes it worth a commercial viable product for food packaging.
\end{abstract}

\section{Keywords: Cucurbita pepo, Musa paradisiaca, Liquid food packaging material,} Moisture and Amylose content, Spectral analysis, Anti-microbial studies.

\section{INTRODUCTION}

One of the foremost challenges in dry waste management is the plastic waste, which leaches out harmful chemicals inadvertently into the environment. The durability and increasing usage of plastics creates a major waste management problem which accounts for approximately 10 per cent of the waste generated ${ }^{1}$ by man kind. Interaction of plastic waste with soil and water affects their quality and uniqueness ${ }^{2}$, the toxic gases from plastics also pollute the environment and increase the global warming. When plastic waste is discarded in landfills, it is viable for the percolation of the hazardous chemical into the potable water ${ }^{3}$ affecting its quality. Due to these environmental issues, some alternative methods are used for the preparation Bio-plastics. Bio-plastic is usually developed from a renewable source like starch, sawdust, cellulose, food waste, vegetable fats, and oils which is used for the packing of cutlery, crockery, food items etc. ${ }^{4}$ The production of Bio-plastics can significantly reduce the emission of greenhouse gases and it can also decrease the consumption of non-renewable energy sources. The present study aims to prepare and analyze the Bio-films obtained from Cucurbita pepo and Musa paradisiaca using 1,2,3-Propanetriol, Gingelly oil, and Agarose gel as the plasticizing agents. In the

This is an Open Access article licensed under a Creative Commons license: Attribution 4.0 International (CC- BY). Published by Oriental Scientific Publishing Company @ 2018

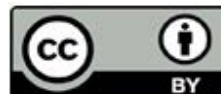


last few years, Glycerol (1,2,3-Propanetriol) has been used in commercial applications because of its properties like high tensile strength, solubility in water, and biodegradability. It is also generally used as a plasticizing agent to increase the flexibility of the Bio-plastic film. Apart from 1,2,3-Propanetriol, Gingelly oil and Agarose gel has been used as plasticizers in this study. The bio-films obtained were further analyzed and characterized by different spectral and surface investigation techniques.

\section{MATERIALS AND METHODS}

\section{Abstraction of starch}

The dry pulp of Cucurbita pepo and peels of Musa paradisiaca was ground into a fine powder, soaked in water for about a day, filtered and used for the abstraction of its starch content. Finally, the dried starch from Cucurbita pepo and Musa paradisiaca was used for further studies.

$$
\text { Yield }(\%)=\frac{\text { Mass of the starch extracted in } g}{\text { Mass of the peel/pulp in } g} \times 100
$$

\section{The Moisture content of Starch}

About $3 \mathrm{~g}$ of the starch samples were taken in the pre-heated, cooled Petri-dishes and kept in the oven at a temperature of $125^{\circ} \mathrm{C}^{5}$. After an hour it was cooled to room temperature and the moisture content of the sample was found out using the following equation (2).

$$
\text { Moisture content }(\%)=\frac{\text { Dried weight of the sample }}{\text { Wet weight of the sample }} \times 100
$$

\section{Ash content}

About $3 \mathrm{~g}$ of the starch samples were incinerated and completely carbonized in the preheated and cooled crucibles for about an hour at $100^{\circ} \mathrm{C}$. After cooling, the percentage of ash content ${ }^{6}$ was calculated using equation (3).

$$
\text { Ash Content }(\%)=\frac{\text { Dried sample weight }}{\text { Wet sample weight }} 100
$$

\section{Starch pH}

About $2 \mathrm{~g}$ of the starch sample obtained from Musa paradisiaca and Cucurbita pepo was shaken in distilled water for 25 min the starch was let on to clear and the $\mathrm{pH}$ was measured using a Systronics, Digital pH Meter 335 with $7 \%$ buffer solution.

\section{Titratable acidity}

$0.1 \mathrm{M}$ of Sodium Hydroxide was used as the titrant for $3 \mathrm{~g}$ of the starch sample dissolved in $30 \mathrm{~mL}$ of deionized water using phenolphthalein as the indicator.

\section{Test for Amylose and Amylopectin content}

About $1 \mathrm{~mL}$ of ethanol and $9 \mathrm{~mL}$ of $\mathrm{NaOH}$ were added to $0.1 \mathrm{~g}$ of the starch sample in a test tube covered by an aluminum foil, after which it was completely mixed and heated for about 10 minutes $^{7}$. The cooled dispersion was diluted to10 times it's volume from which $0.5 \mathrm{~mL}$ of the extract was used for the analysis. To the extract, $0.1 \mathrm{~mL}$ of $\mathrm{CH}_{3} \mathrm{COOH}$ and $0.2 \mathrm{~mL}$ of $\mathrm{I}_{2}$ in $\mathrm{CCl}_{4}$ were added and made up to $10 \mathrm{~mL}$ with distilled water. The Amylose content was determined using Aer Infra Digi, Digital Photo Colorimeter. The Amylose and Amylopectin content (\%) was determined using equations 4 \& 5 .

Amylose content $(\%)=\mathrm{pH}$ value $\times$ Absorbance $\times 20$

Amylopectin content $(\%)=100$-Amylose content $(5)$

\section{Preparation of the Bio-film}

The bio-films were made using the starch of Cucurbita pepo and Musa paradisiaca. The bio-plastic from Cucurbita pepo was developed by taking $3 \mathrm{~g}$ of its starch to which a mixture of $2 \mathrm{~g}$ of agarose gel and $2 \mathrm{~mL}$ of gingelly oil was added and heated in a low flame to get a colloidal gel. The gel was spread on a flat aluminum foil and dried ${ }^{8}$ under the sunlight for two days to obtain the bio-film. About $3 \mathrm{~g}$ of Musa paradisiaca peel was soaked with sodium metabisulphite $\left(\mathrm{Na}_{2} \mathrm{SO}_{3}\right)$ for about 45 minutes. Then, the peel was boiled for half an hour, filtered, dried, and ground into a paste. $2.5 \mathrm{~g}$ of Musa paradisiaca paste was taken to which, $3 \mathrm{~mL}$ of sodium hydroxide, $3 \mathrm{~mL}$ of hydrochloric acid, and $2 \mathrm{~mL}$ of 1,2,3-Propanetriolwere added and mixed well. The mixture was poured into a petri dish, and heated for about half an hour at $110^{\circ} \mathrm{C}$ in an oven. After cooling a brown-colored bio-plastic film was formed.

\section{Water Holding Capacity of the film}

The bio-film was cut into $2 \mathrm{~cm} \times 2 \mathrm{~cm}$ size and placed into a beaker containing $100 \mathrm{~mL}$ of water ${ }^{9}$ for an hour. The initial and final weight of the films were noted from which the water holding capacity of the films was calculated using Equation (6), 


$$
\text { Water uptake }(\%)=\frac{\text { Final wt. of the bio-filming - Initial wt. of the sample ing }}{\text { Final weight of the bio-film in } g} \times 100
$$

\section{Biodegradability test}

About $2 \mathrm{~g}$ of the bio-film was taken and buried under the soil in a beaker at the depth of 5 $\mathrm{cm}$ from the ground surface for about 15 days. The weight of the film was taken in a cycle of three days and results were recorded accordingly ${ }^{10}$. The weight of the sample before $\left(W_{0}\right)$ and after burial $\left(W_{f}\right)$ in the compost soil was noted and the weight loss of the samples was calculated using Equation (7),

Weight loss $(\%)=\frac{W_{0}-W_{F}}{W_{0}} \times 100$

\section{Bio-films as Liquid food Packaging Material}

Both the bio-films of Cucurbita pepo and Musa paradisiaca were tested as a packaging material for liquid food. The pre-weighed bioplastic $\left(\mathrm{W}_{1}\right)$ was cut into $2 \times 2 \mathrm{~cm}$ and immersed in normal water and coconut oil at room temperature for three hours after which it was re-weighed $\left(\mathrm{W}_{2}\right)$. The weight change (\%) of the bio-film was calculated using Equation.8. If the weight change of bio-film after being plunged into the liquid food products is less than $15 \%$ then the bio-film is to be compatible with the liquid food product and can be used as a packaging material for the same.

$$
\Delta \mathrm{W}(\%)=\frac{\mathrm{W}_{2}-\mathrm{W}_{1}}{\mathrm{~W}_{2}} \times 100
$$

\section{Characterization of the Bio-films}

The investigation of the bio-films was carried out by different Spectral and Surface Analyzing techniques.

\section{FT-IR analysis}

The functional groups present in the films were determined through an Attenuated Total Reflectance (ATR) accessory with 8 scans at the range of $4000-400 \mathrm{~cm}^{-1}$ (Perkin Elmer FT-IR Spectrometer Frontier). The Bio-film was mixed $\mathrm{KBr}$ in a ratio of $1: 5^{11}$. The peaks were obtained in the range of 4000 to $400 \mathrm{~cm}^{-1}$.

\section{SEM analysis}

The surface morphology of a biopolymeric film can be visualized using scanning electronic microscope ${ }^{12}$ under normal atmospheric conditions. The SEM analysis utilizes a focused beam of highenergy electrons to produce an assortment of signals at the surface of the specimens.

\section{Antimicrobial Activity Test}

The antimicrobial activity of the bio-film for micro-organisms was done by the Disc-diffusion method $^{13}$. The Petri dish was prepared with Muller Hinton Agar and immunized with test organisms. Sterile disc of 6-millimeter width was infused with the bioplastic film at different concentrations of 20-100 microgram per milliliter respectively. The impregnated disc was placed on the top layer of agar plates for $30 \mathrm{~min}$ at room temperature for compound diffusion. The dishes were incubated for $24 \mathrm{~h}$ at $37^{\circ} \mathrm{C}$ and the zone of inhibition was recorded in millimeters and the experiment was repeated twice.

\section{RESULTS AND DISCUSSION}

\section{Yield of Starch}

The percentage yield of starch from Cucurbita pepo and Musa paradisiaca is given in Table 1 From the values it can found that biofilms prepared from the starches can be used as a

\begin{tabular}{|c|c|c|c|}
\hline No & Parameters & Curcubita pepo & Musa paradisiaca \\
\hline 1 & Appearance & Yellow & Brown \\
\hline 2 & Odor & Odorless & Odorless \\
\hline 3 & $\%$ yield & 76.25 & 82.9 \\
\hline 4 & $\mathrm{pH}$ & 5.30 & 6.64 \\
\hline 5 & Titrable acidity & 3.8 & 3.5 \\
\hline 6 & Moisture content & 11.99 & 11.9 \\
\hline 7 & Ash content & 5.86 & 3.9 \\
\hline 8 & Amylose Content & 20.27 & 34 \\
\hline 9 & Water Holding Capacity & 63.68 & 89 \\
\hline
\end{tabular}
packaging material for food products.

\section{Moisture content}

The moisture content for Cucurbita pepo starch and Musa paradisiaca starch was found to be in the range of $11-12 \%$ (Table 1 ). The result shows that the moisture content value for both starches is low when compared to other starches ${ }^{14}$ which may be due to reasons like handling problems and level of ripping. High moisture content in food can lead to microbial spoilage and short shelf life to the food items, leading to its deterioration. Less percentage of moisture content in food items is acceptable and good.

\section{Ash content}

The mineral content of the bio-film ${ }^{15}$ is identified by the ash test. The ash content of both Cucurbita pepo and Musa paradisiaca starches was 
found in the range of 3-5\%. The mineral and organic salt in the tubers is expressed as the ash content which is the food residue after the combustion process. The low value of ash indicates a low mineral content in the fruit or the vegetable under investigation.

\section{$\mathrm{pH}$ of the starch}

The $\mathrm{pH}$ value of the Cucurbita pepo and Musa paradisiaca starches were found to be around 5-7. If the $\mathrm{pH}$ of the starch is in the range of $4-7^{16}$ it can be used as a packaging material in food industry.

\section{Amylose content}

The Amylose content test will help to detect the Amylose and Amylopectin percentage in the starch. The Amylose content present in the Cucurbita pepo (20.27\%)and Musa paradisiacal (34\%) is given in Table 1. The Amylose content leads to chain formation in the bioplastic preparation.

\section{Water Holding Capacity of the Bio-film}

The water holding capacity is an important study to determine the suitable source for biopolymers. ${ }^{17}$ The water uptake value of the bio-plastic sheet from Musa had $89 \%$ percentage followed by Cucurbita pepo bio-plastic sheet with $63.68 \%$ of absorption capacity (Table 2 ). Due to the hydrophilic nature of the films the water upholding capacity was found to be more than $50 \%$ and this may be due to the plasticizing agent 1,2,3,-propanetriol. It is a low molecular carbohydrate that tends to absorb water according to the molecular weight of its structure ${ }^{18}$ and the number of hydroxyl groups present in it.

Table 2: The weight change of the bio-plastics after being immersed in test samples for one hour

\begin{tabular}{cccc}
\hline No & Test samples & Curcubita pepo & Musa paradisiaca \\
\hline 1 & Distilled water & 63.68 & 89 \\
2 & Vegetable oil & 2.9 & 4.87 \\
\hline
\end{tabular}

Application of bio-films as a Packaging Material for Liquids

From Table 2 it can be seen that the penetration of vegetable oil is low compared to the penetration of water in the synthesized bio-films. The weight of the biofilm increased to a maximum than its original weight. This indicates that the bio-plastic of Cucurbita pepo and Musa paradisiaca can be used as a packaging material for vegetable oils.

\section{Biodegradability test}

The degradation tests of bio-films was conducted using the soil burial technique. The biodegradability of bioplastics was determined by allowing them to degrade in the soil for a month. The degradation of Cucurbita pepo and Musa paradisiaca bio-film was monitored regularly. Fig. 1 \& 2 show the percentage weight loss of the samples within one month for Cucurbita pepo (87\%) and Musa paradisiaca ( $93 \%$ ) respectively. Generally, the results show the increase in the percentage of degradation of the bio-film gradually after five days. The weight loss was monitored periodically for every five days and after 30 days it was found to be fully degraded. Visually the texture of the bio-plastics showed literal damage on the surface of the bio-plastics ${ }^{19}$.

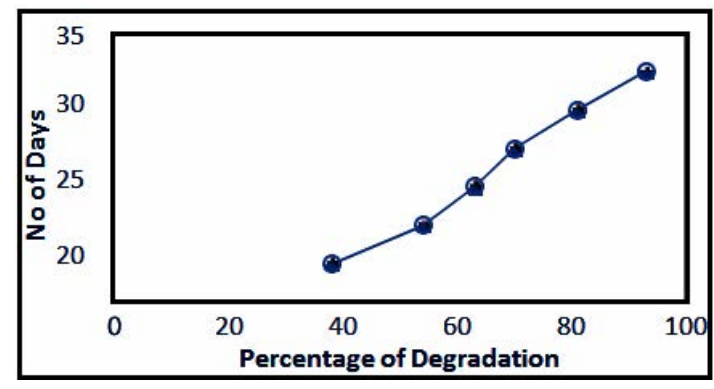

Fig. 1. Degradation percentage of bio-film from Curcubita pepo

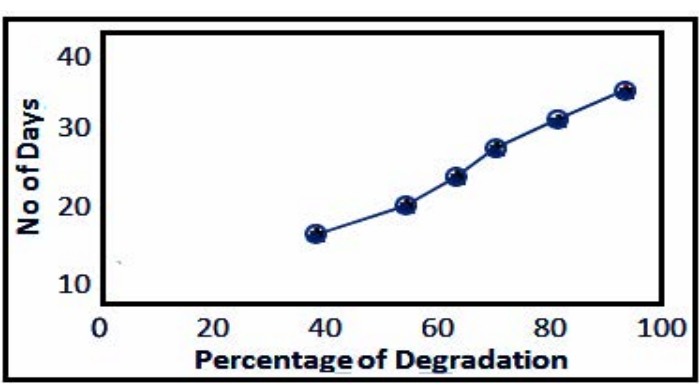

Fig. 2. Degradation percentage of bio-film from Musa paradisiaca

\section{Spectral Analysis of the Bio-films}

Figure 3 and 4 show the IR spectra of Cucurbita pepo and Musa paradisiaca. In the IR spectrum of Cucurbita pepo bio-film the characteristic peak at $3605.99 \mathrm{~cm}^{-1}$ shows the presence of $\mathrm{O}-\mathrm{H}$ stretching bond ${ }^{20}$, the peak at $2326.18 \mathrm{~cm}^{-1}$ shows $\mathrm{O}=\mathrm{C}=\mathrm{O}$ stretching bond ${ }^{21}$, the absorption bands at $2155.99 \mathrm{~cm}^{-1}$ and $1743.92 \mathrm{~cm}^{-1}$ shows the presence of $\mathrm{N}=\mathrm{N}=\mathrm{N}$ and $\mathrm{C}=\mathrm{O}$ stretching and the band at $1472.50 \mathrm{~cm}^{-1}$ shows $\mathrm{C}=\mathrm{C}$ ring stretching aromatic bond. The characteristics peaks at $3205.90 \mathrm{~cm}^{-1}$, $2957.66 \mathrm{~cm}^{-1}, 2132 \mathrm{~cm}^{-1}, 1421 \mathrm{~cm}^{-1}$ and at $857 \mathrm{~cm}^{-1}$ of the Musa paradisiacal biofilm were attributed to $\mathrm{N}-\mathrm{H}$ stretching (secondary amine) hydrogenbonded nitriles, strong $\mathrm{C}-\mathrm{H}$ stretching (alkanes) ${ }^{22}$, 
$\mathrm{C} \equiv$ Calkynes, C-H stretching (alkene) and aromatic $\mathrm{C}-\mathrm{H}$ stretching respectively in the FT-IR Spectrum.

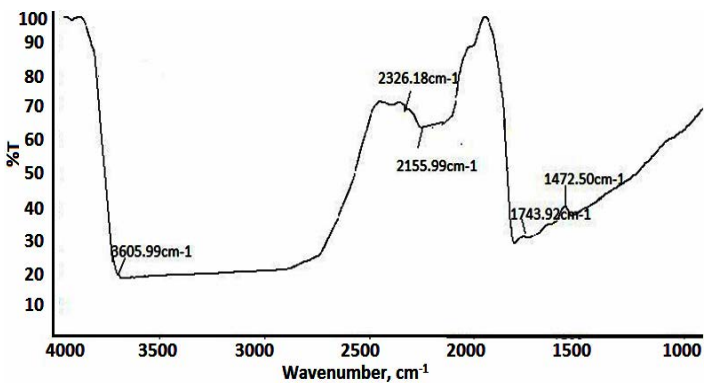

Fig. 3. FT-IR Spectra of the bio-film from Cucurbita pepo

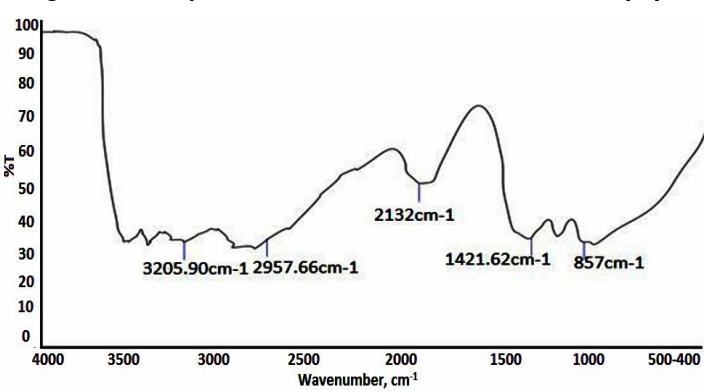

Fig. 4. FT-IR spectra of the bio-film from Musa paradisiaca

\section{Surface analysis technique}

The scanning electron microscopy studies showed that Musa paradisiaca starch granules ${ }^{23}$ are rectangular (Fig. 5) with a smooth surface. The starch granules of Cucurbita pepo were found to be spherical with a smooth surface (Figure 6).

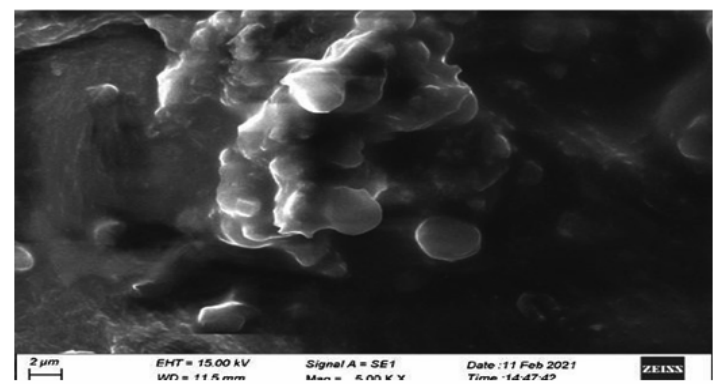

Fig. 5. Sem image of the developed bio-film from Musa paradisiaca

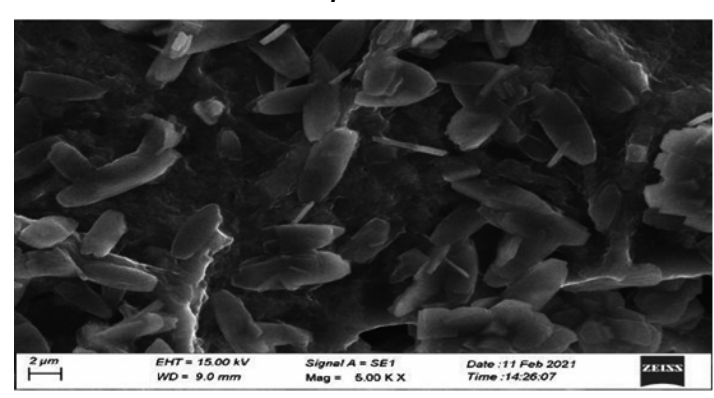

Fig. 6. Semimage of the developed bio-film from Cucurbita pepo

\section{Anti-microbial Activity}

The anti-fungal and anti-bacterial results of Cucurbita pepo and Musa paradisiaca bio-films reveal that both the starches are effective against Aspergillus niger ${ }^{24}$ and Staphylococcus aureus ${ }^{25}$ compared to Escherichia coliand Candida albicans. The results are given in Tables 3 and 4.

Table 3: Antifungal activity of the plant starches

\begin{tabular}{lccc}
\hline Starch & $\begin{array}{c}\text { Concentration } \\
(\mu \mathrm{l} / \mathrm{disc})\end{array}$ & \multicolumn{2}{c}{ Organisms/Zone of Inhibition } \\
Candida albicans & Aspergillus niger \\
\hline Curcurbito pepo & 100 & 5 & 6 \\
Musa paradisiaca & 100 & 3 & 4 \\
\hline
\end{tabular}

Table 4: Anti-bacterial activity of the plant starches

\begin{tabular}{lccc}
\hline Extract & Concentration $(\mu \mathrm{l} / \mathrm{disc})$ & \multicolumn{2}{c}{ Organisms/Zone of Inhibition } \\
& Escherichia coli & Staphylococcus aureus \\
\hline Curcurbita pepo & 100 & 7 & 6 \\
Musa paradisiaca & 100 & 5 & 8 \\
\hline
\end{tabular}

\section{CONCLUSION}

The development of packaging material for food products involves sustainability and environmental responsibility. In this study, Cucurbita pepo and Musa paradisiaca starch have been used for the preparation of bio-films. The bio-film also investigated by spectral and surface morphological analysis. Anti-microbial studies showed that the biofilms were effective against Aspergillus niger and Staphylococcus aureus. The different physical and chemical properties like percentage yield of starch, $\mathrm{pH}$, Titrable acidity, proximate analysis like amylose content and moisture content of the biofilm showed that it can be used as an alternative food packaging material for vegetable oils. 


\section{ACKNOWLEGDEMENT}

The authors wish to accord their sincere thanks to the Principal and Management of Holy
Cross College (Autonomous), Tirichirapalli.

\section{Conflict of interest}

The author declare that we have no conflict of interest.

\section{REFERENCE}

1. Richard Thompson, C.; Shanna Swan, H.; Charles Moore, J.; and Fredrick Vom Saal, S. Phil. Trans. R. Soc. B., 2009, 364,1973-1976.

2. Rizwana Beevi, K.; Sameeera Fathima, A.R.; Thahira Fathima, A.I.; Thameemunisa, N.,Noorjahan, C.M.; Deepika, T. Int. J. Sci. Technol. Res., 2020, 9, 22-29.

3. Marichelvam, M.K.; Mohammad Jawaid ; Mohammad Asim, Fibers., 2019, 7, 32.

4. Noor Fathimah; Kader Sulfan; Wan Lutti Wan Tohari; BSTR., 2017, 5, 12-17.

5. Indrianingsih, A.W.; Apriyana, W.; Nisa, K,; Rosyida, T.; Hayati, N.; Darsih, C.; Kusum aningrum, Food Res., 2019, 3(5), 484-490.

6. Workiye Getnet Abera, Int. J. Biol. Macromol., 2019, 1, 1-130.

7. ArifaShafqa; Nabil Al-Zaqri; Arifa Tahir; Ali Alsame; Saudi J. Biol. Sci., 2021, 28, 1739-1749.

8. Vikas Mishra; Akash Patel; Darshan Rana; Sanjay Nakum; and Bhupendra Singh; IJSRD., 2015, 452-455.

9. Jose Igor Hleap- Zapata ; Therlyn CruzRosero; Laely Tafiana Duran- Rojas; Daniela Hernandez -Trujillo; Luis David ReinaAguirre; Natalia Tilano-Pemberthy, J of faculty of Agr. Sci., 2020, 52(2), 395-404.

10. Jayachardra Yarododai; Vinay Patil; Sharanabasava Gabachari and Nagaraj, IJPRAS., 2016, 5, 56-66.

11. Aline Machado Pereira; Fernanda Doring Ramos; Ana Cristina Richte Kroow; Roberta Bascle Santos; Marcia Aricha Gularta, Food Sci. Technol., 2020, 40, 352-487.

12. Htun Htun Naing; Htay Htay Shwe ; Ni Ni Pe;
Yazar Tun, Res. J. Chem. Environ., 2020, 3(4), 1353-1361.

13. Augustin, Y.E.; and Padmawjiya, K.S.; Mater. Sci. Technol., 2017, 1-7.

14. Abubakar,U.S.;Yusuf, K.M.;Safiyan, I.; Abdilahi, S.; Saidu, S. R. Int. J. Food. Sci. Nutr., 2016, 1, 25-27.

15. Raden Cecep; Erwan Andriansyah; Taufik Rahman; Ainia Herminiati; Nurhaidar Rahman; Rohmah Luthfiyanti, IOP Conf. Ser.: Earth Environ. Sci., 2017, 101, 1-10.

16. Rowe, R.C.; Sheskey, P.; Quin, M.E.; J. Pharm. Pharmacol., 2017, 8, 506-509.

17. Noor Fatimah Kader Sultan; Wan Lutfi Wan Johari, BSTR., 2017, 5, 12-17.

18. Mathew, A. P.; Dufresne, A.; Biol. Macromolecules., 2002, 3(5), 1101-1108.

19. Oluwasina, O. O.; Olaleye, F. K.; Olsegun, S. J.; Mohallem, N. D. S. Int. J. Biol. Macromol., 2019, 135, 282-293.

20. Ling Yin; Changlin Wang, J. Hortic., 2016, 3, 187.

21. Hasan, M.; Zulfadli Nazar, M; Rahmayani, R.F.I.;Fajri, G.; Fansuri. H. Rasayan J. Chem., 2019, 12, 1390-1398.

22. Asep Bayu Dani Nandiyanto; Rosi Oktiani; Risti Ragadhita; IJoST., 2019, 4(1), 97-118.

23. Heloisa Tibolla.; Franciele Maria Pelissari.; Florencia.; Cecillia Menagalli.; Food Sci. Technol., 2014, 59, 1311-1318.

24. Ali Nasse.; Saddiq Amna.; Afr. J. Microbial. Res., 2012, 6(41), 6941-6947.

25. Amal, A.; Aljuraifani.; Asian J. Biol. Sci., 2017, 26(2), 229-235. 